\title{
The Image of Chatsky in the Opera "Woe from Wit" by G.I. Banshchikov
}

\author{
Maria V. Kholodova* \\ Krasnoyarsk State Institute of Arts \\ 22 Lenin Str., Krasnoyarsk, 660049, Russia
}

Received 20.02.2016, received in revised form 24.03.2016, accepted 28.06.2016

Gennady Ivanovich Banshchikov is one of the greatest composers of our time. The article presents some results of the study of the musical-theatrical legacy of G.I. Banshchikov.

The author focuses his attention on the composer's opera created on the plot of the famous comedy by A.S. Griboyedov. The mastery of the author-playwright, unfolding the artistic and semantic contexts of a literary source by musical means, is demonstrated through analyzing the image of the work's main character-Chatsky.

Keywords: G.I. Banshchikov, domestic musical theater, classical Russian literature, opera.

DOI: 10.17516/1997-1370-2016-9-8-1799-1811.

Research area: culture studies.

In 1979, G.I. Banshchikov, violating his own goal not to write without an order, addressed to one of the highly anticipated stories in the domestic musical theater that was the famous comedy Woe from Wit by A.S Griboyedov.

The composer's opera, completed in 1984, organically integrated into the mainstream of the artistic processes taking place in the domestic musical theater of that period (Voitkevich, 2014). Among them is a steady composer's interest in the stories of Russian and foreign classics, which gave rise to a number of theatrical works of intellectual and philosophical direction, whose authors tried to make sense of the modern picture of the world, seeking answers to the 'eternal' questions (Deval'er, 2011: 75-76).

G. Banshchikov also joined these spiritual quests in the opera Woe from Wit. The emphasis on social and moral issues, philosophical and psychological reflection made this work the center of the intersection of the artistic quest of the composer in the field of musical theater (Kholodova, 2011: 8).

According to the author, the idea of the creation arose in high school, when at literature lessons he was learning Griboyedov's play, '... after seeing Act 3 (the gossip about Chatsky, its development), and the tragic end, I felt that I badly wanted to take up the opera $<\ldots>$ I even started to write something ... ' (Kholodova, 2014). G. Banshchikov achieved his dream to

(C) Siberian Federal University. All rights reserved

* Corresponding author E-mail address: holodova-maria@mail.ru 
write an opera about Chatsky nearly thirty years later. Then all it favored the successful completion of the work, namely, enthusiasm for the chosen theme, maturity and songwriting skill acquired by the time, a happy possibility of a future theatrical production. The flamboyant opera was born as a result of such 'terms'. In our view, it is on a par with Dead Souls by R. Shchedrin, Peter I by A. Petrov, The Master and Margarita and Mary Stuart by S. Slonimsky, which are the best achievements of the national opera of 70-80s of the $20^{\text {th }}$ century.

The libretto by G. Banshchikov (who did not trust anyone to work on the literary basis of his creation) can be considered a creative success. All amendments, changes, proof did not violate the integrity of the drama, the inner, deep sense of the 'core' of the comedy. The composer was able to create a dynamic, compact, well thought-out libretto in theatrical terms, essentially preserving the artistic merits of the original. The author did an incredibly complex and painstaking work on the compression of the text. As a result of numerous omissions and cutting out of side storylines, about one-third of the text remained, but this was certainly forced sacrifices dictated by the laws of the genre of opera.

The drama of the work by G. Banshchikov is conditioned by the literary source. Two dramatic storylines, namely the lyrical one (Chatsky's love to Sophia, Sophia's love to Molchalin that is a traditional love 'triangle') and the social one (the opposition of the main character to the Moscow 'high society') became the foundation of the dramatic conflict of the opera. The opera has a double introduction of the dramatic conflict, resulting in the presence of two semantic climaxes, distributed in different sections of the form.

The choral scene of 'slander' in the $3^{\text {rd }}$ scene, where the Moscow society, gathered at
Famusov's ball, 'held up' Chatsky to madness, became the climax of the socio-accusatory line. The climax of the lyrical line is in the $4^{\text {th }}$ scene when Chatsky learns of the betrayal of Sophia (and she, in turn, learns about the hypocritical nature of the 'object' of her love that is Molchalin). The first climax, resolved in a grotesque accusatory way, is more significant in the semantic context of both Griboyedov's play and the opera. Intertwined with the lyrical line, they reveal Chatsky's 'drama of the heart' and 'drama of the mind'.

G. Banshchikov's sensitive vision of the multidimensional ideological and artistic concept of the comedy found a bright reflection in the figurative and intonation drama of the opera "Woe from Wit", in the center of which is Alexander A. Chatsky. Let us recall that just after appearing on the literary 'scene' in the 20 s of the $19^{\text {th }}$ century, this character immediately became the object of an intense study, the center of gravity of critical thought. The image was so contradictory that caused conflict points of view of contemporary critics.

After coming to the creation of the opera, G. Banshchikov immediately faced the problem of ingenuity of Griboyedov's character. However, the composer 'read the hero of the play as an exceptional, chivalrously noble, romantic and exalted character. The intense intellectual reflection became defining in the musical characteristic of Chatsky, but at the same time the composer got across the raging passions of his soul.

Suchacomplex emotionaland psychological nature of the image of Chatsky was discovered by G. Banshchikov in the subject, which opens the opera (Pattern 1). Its sudden invasion at $\boldsymbol{f} \boldsymbol{f}$ seemed to 'explode' the moment of awaiting the start of the stage action, like the sudden visit of Chatsky to Famusov's house where he is destined to fail. 
Pattern 1

Allegro

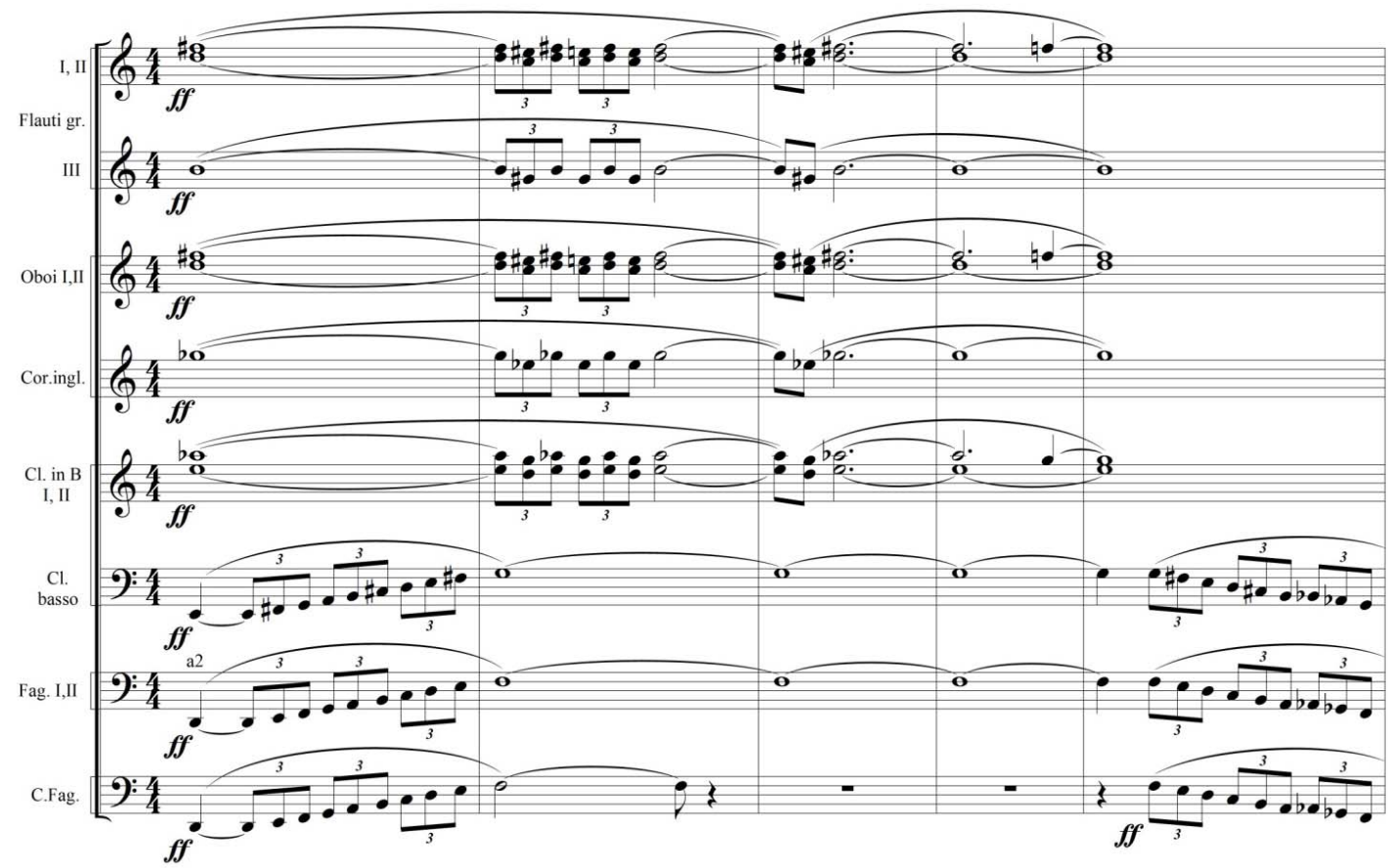

The multicomponent texture stands out in the expressive complex of the theme. It has two planes. The lower plane is represented by the triplet melodic rise, 'taking off' like an unwinding 'spring' in a range of decima of low woodwind and string instruments (d-Dorian).

The upper plane of the texture is a motion with parallel triads in the volume of a minor second, set out by a group of woodwind instruments (h-moll). The triplet rhythm embodies the state of inner impulse, confusion, emotion of the character, while the alternating chords of tonic and augmented triads reinforce the ambiguity, and 'mystery' of the romantic nature.

This principle of organization of musical material in a polytonal type of planes' relations, the chromatic intonation sphere, the dissonant harmonic vertical facilitate the transfer of a dual, disharmonious image of Chatsky. It is important that the two planes of the theme's texture are closely linked with respect to rhythm: the upper is a rhythmovariant of the original figure that is the upward motion of the lower voices of the lower plane. The theme ends with the triplet downward motion in the part of low strings. A mirror type of structural organization is created; it seems to 'lock' the character in the space of his own world.

Let us pay attention to one fact. The melodic 'core' of the theme is the intonation of a minor second, which, as one of the most common in the composer practice of musical tokens, represents 'the suffering' beginning of the image, since the character is in for the betrayal in love. In addition, the rhythmoformula of Destiny 'emerges' in the rhythmic pattern in the $2^{\text {nd }}$ time. Such semantic associations enhance the tragedy of the image of Chatsky.

Taking into account the continued functioning of the theme, it can be designated as the leitmotifcharacter. It will accompany both the moments of mentioning Chatsky (e.g., talking Lisa and Sophia 
in the $1^{\text {st }}$ scene, fig. 30), and his 'real' appearances on stage. Staying largely unchanged in rhythmmelodic terms, the theme varies only in terms of pitch and timbre-harmonic context.
The orchestral conducting of the leitmotif defines stage scenic situations, bonding the opera composition:

\begin{tabular}{l|l|l|l|l}
\multicolumn{1}{|c|}{ Overture } & \multicolumn{1}{|c|}{ Scene 1 } & \multicolumn{1}{c|}{ Scene 2 } & \multicolumn{1}{c}{ Scene 3 } & \multicolumn{1}{c}{ Scene 4 } \\
\hline---- & $\begin{array}{l}\text { Visit of Chatsky } \\
\text { Talking Chatsky and } \\
\text { Sofia }\end{array}$ & $\begin{array}{l}\text { Monologue } \\
\text { I wonder who the judges } \\
\text { are!' }\end{array}$ & $\begin{array}{l}\text { Monologue } \\
\text { 'The Little Frenchman } \\
\text { from Bordeaux' }\end{array}$ & $\begin{array}{l}\text { Appearance of Chatsky } \\
\text { in the scene of Sofia and } \\
\text { Molchalin }\end{array}$ \\
\hline & fig. 35, h-moll & fig. 77, h-moll & fig. 151, c-moll & fig. 179, t.13, c-moll
\end{tabular}

The entrance presents another theme that complements the portrait characterization of the main character $(6-7 \mathrm{tt}$.). The short, concise motif embodies the oratorical pathos of statements and pathetic feelings of Chatsky (Example 17). It is performed by $\boldsymbol{f}$ trumpets and trombones at the ostinato harmonic 'pedal' of the orchestra, creating a sharply dissonant harmonic vertical.
The intonation basis of the leitmotif is a rising fourth, which in combination with the expressive dotted rhythm, 'soaring' progressive melodic phrases, underlined accents of each duration, symbolizes the decisive and uncompromising character of Chatsky.

At the same time, the two phrases are completed with descending second 'drops', as if symbolizing the futility of the character's striving in defending his ideals.

\section{Pattern 2}

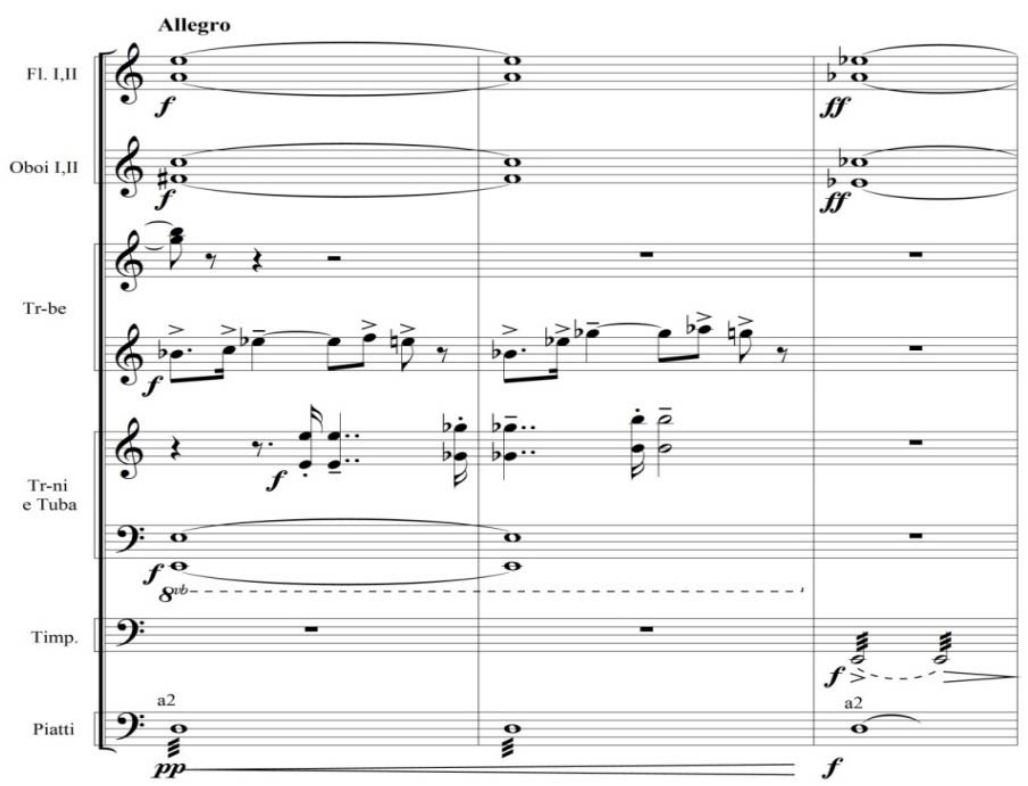

The rich semantic potential of leitmotifs of Chatsky significantly expands the scope of their functioning in musical dramatic art. They do not just make the character more vivid, but focus 'the grain' of the drama of Chatsky inside themselves. In all the components of thematic invention the composer emphasizes the main idea of the work that is the predetermined destiny of the character, 
betrayed by his beloved and slandered by 'the Moscow society'. In this regard, it is no coincidence that in the entrance the thematic invention of Chatsky interacts with other themes. Thus, at the climax of the development of the $2^{\text {nd }}$ leitmotif, a new theme appears in groups of strings and woodwind as its continuation. This is the theme of Sophia. It consists of two cantilena phrases.
Their conclusion 'breaks' with a sharp crescendo from $\mathbf{p}$ to $\boldsymbol{f} \boldsymbol{f}$, as if giving the inner expression of the feelings of the heroine. The theme will be her leit-characteristic in the following. The intonation shape of the melodic line of a song and romance constitution is determined by the minor second, embodying the lyrical beginning associated with the image of Sophia.

\section{Pattern 3}

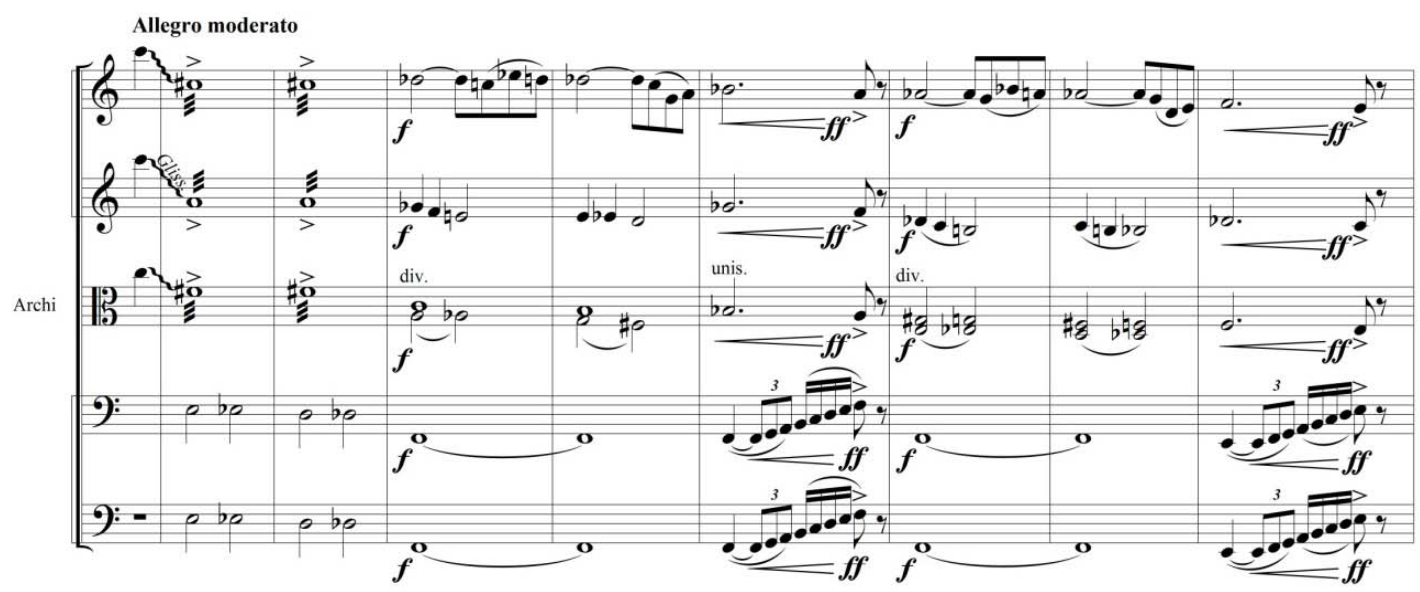

The lamento intonation 'penetrates' into all levels of orchestral textures, thereby forming the accompanied condensed-dissonant harmonic vertical. The chromatic octave step in the basses preceding the leitmotif of Sophia with 'flat' half-note durations (in low wooden and string instruments) is extremely important. It detects the connection with a well-known rhetorical figure passusduriusculus, which is an expression of suffering and doom. Using these intonation 'signs', the composer seems to portend dramatic collisions in the fate of the heroine. The introduction of the rhythmointonation figure of the $1^{\text {st }}$ leitmotif of Chatsky (fig.1, 3; 6 tt.) into the texture of the theme of Sophia reveals the relationship of the main characters. In the same context, it is necessary to consider the invasion of the theme related to the image of Famusov at the climax of the musical development of the $2^{\text {nd }}$ leitmotif of Chatsky, and his leitmotif in the following. It is a chain of chromatically 'slipping' seventh chords. The leitmotif sounds majestically and menacingly from the orchestra tutti in $\boldsymbol{f f f}$ dynamics. 


\section{Pattern 4}

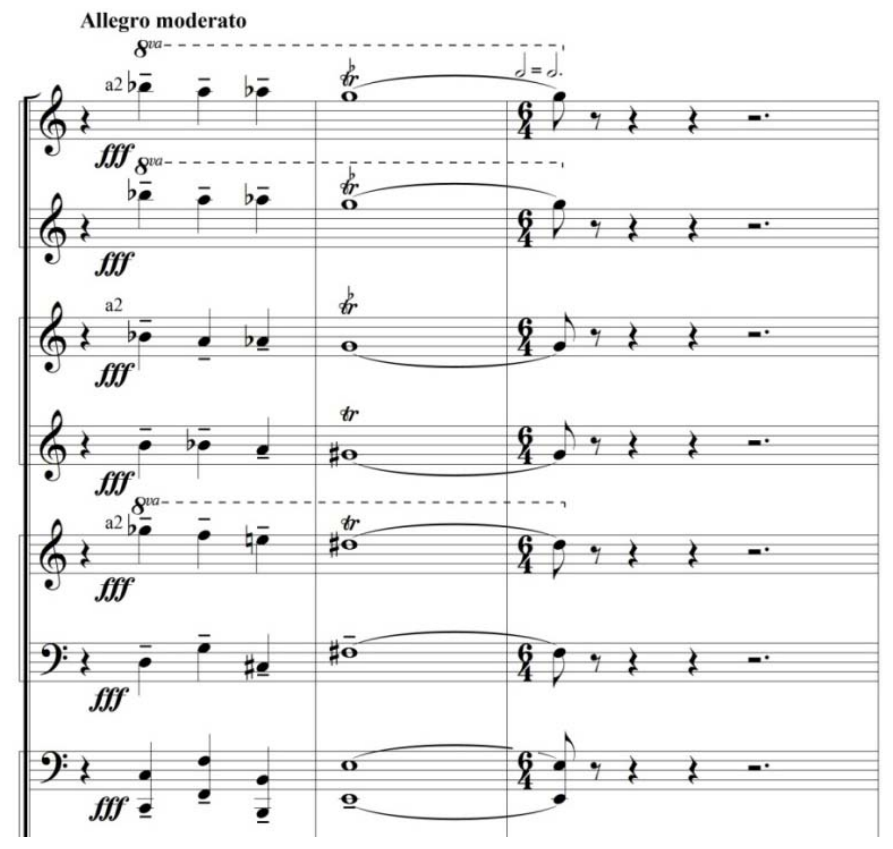

The 'hard', sharply dissonant chord vertical and the rhythmoformula, close to the theme of Destiny (given in the rhythmical increase), draw the imperious, imperative character of the house owner. The theme is endowed with the status of symbol that embodies a hostile force that dominates Chatsky, prejudging the further dramatic outcome.

The leitmotif of the main character, presented in the Entrance, possess an extremely significant role in the figurative and intonation drama of the opera, because they are a kind of 'foundation' of the thematic area related to this character. It is symptomatic that the leitmotifs will function in close cooperation.

At the same time, the $2^{\text {nd }}$ leitmotif exists in the dramatic context in a more active form. It seems, this is due to the fact that, passing the essence of the plot of the play by Griboyedov and opera by G. Banshchikov, it represents not only the image of Chatsky, but also the idea of social protest, opposition to Famusovism. That is why the $2^{\text {nd }}$ leitmotif not only accompanies the 'central' points of the development of the action, reflecting the turning points of the drama of the character. Each time, depending on the stage situation, it is subjected to timbre and pitch transformations, metrorhythmical and texture modifications, takes on new meaning qualities, expressing the psychological state of the character, his attitude to the current events.

As an illustrative example, we refer to the monologue 'The Little Frenchman from Bordeaux' of Chatsky at the ball (Act 2 / Scene 3 , fig. 151), where the $2^{\text {nd }}$ leitmotif receives a wide symphonic development, preparing the semantic culmination ('I was about to retort; but they broke up, dispersed', fig.153, example 20). The psychological tense in this episode is highlighted by the use of small rhythmic figures, the priority groups of brass wind instruments. The main rhythmoformula of the leitmotif is 'compressed' to the $16^{\text {th }}$ and $32^{\text {nd }}$ durations, the interval of newt is fixed in intonation combinations that ultimately enhances the emotional tension of the scene. 
The $2^{\text {nd }}$ section of the final monologue of Chatsky 'I try to come to reason; but I can't ...' (Act 2 / Scene 4, fig. 189), the appearance of this leitmotifmarks the culmination in the development of the image of the character, determines the denouement of the dramatic conflict. Creating the expressive overtones of the declamatory voice part, it sounds terribly in the rhythmic increase, in the dense choral texture of the low brasses ff. All this fills the expressive musical speech of slandered and disappointed Chatsky with an angry, accusatory pathos, revealing all the depth of his spiritual drama.

Chatsky in the opera is certainly the spokesman of 'the author's' position of rejecting the sanctimonious, narrow-minded world, the embodiment of the confrontation of 'this century and the last century'. The character is in constant conflict with others, enters polemical discussions, showing boldness and directness of judgment, categoricalness in 'sentences' for morals and standards of the secular society. The antagonistic beginning, originally put in the image Chatsky (and increased by the love drama) by Griboyedov, predetermined its tragic direction in the development of the dramatic conflict of G. Banshchikov's opera. 'The halo of the tragic' accompanies the character from his first appearance (Act 1 / Scene 1, 3 t. to fig. 35).

The sudden arrival of Chatsky at the Famusovs' house brings an emotional and psychological dissonance in the scenic situation: running Chatsky, craving for a meeting with his beloved, interrupts the dreamy romance effusions of Sophia about Molchalin in her ardently lyrical aria, 'The one I love is of different make'. It is quite natural that the woman meets him in a cold and hostile manner.
The first vocal phrase of Sofia, addressed to the character 'No, Chatsky, it is nice to see you around.... In contrast to the meaning of words, it consists of the rising newt and two linked quarts, 'revealing' negative emotions of Sophia. Almost a complete absence of the thematic invention of the heroine in this scene-dialogue as if 'wearing a mask' of indifference and ignorance is also symptomatic. The voice part of a small exposure monologue of Chatsky ('It's hardly morning: here I'm down on my knees...') is 'impregnated' with active quart intonations. The melodic line is made up of short syllabic phrases; their rhythmic activity is highlighted with a dotted line, which makes the musical language of the character impulsive: Chatsky impatiently 'deluges' Sophia with questions.

However, in this scene the composer outlines his conflict with the society with a dotted line. The character who does not tolerate hypocrisy, does not want to hide his true feelings, makes enemies in the person of Sophia at once. Their first dialogue is a conflictual encounter, where the thrown jealous phrase 'For this Molchalin you have time!' instantly divides the characters with 'the gap' of misunderstanding. A small duet of 'disagreement' clearly demonstrates that: the angry phrases of Sophia with exaggeratedly wide interval jumps 'You viper!', where the word viper is highlighted with a tritone, sound like a counterpoint to the declamatory voice part of Chatsky, continuing to wit now about the Moscow society in a sarcastic manner.

There is a psychological 'modulation' into the lyric-dramatic sphere only in the subsequent aria-monologue 'I crossed the snowy desert through the day and night. I hurried here at a neck break pace...' (fig. 41, h-moll). 


\section{Pattern 5}

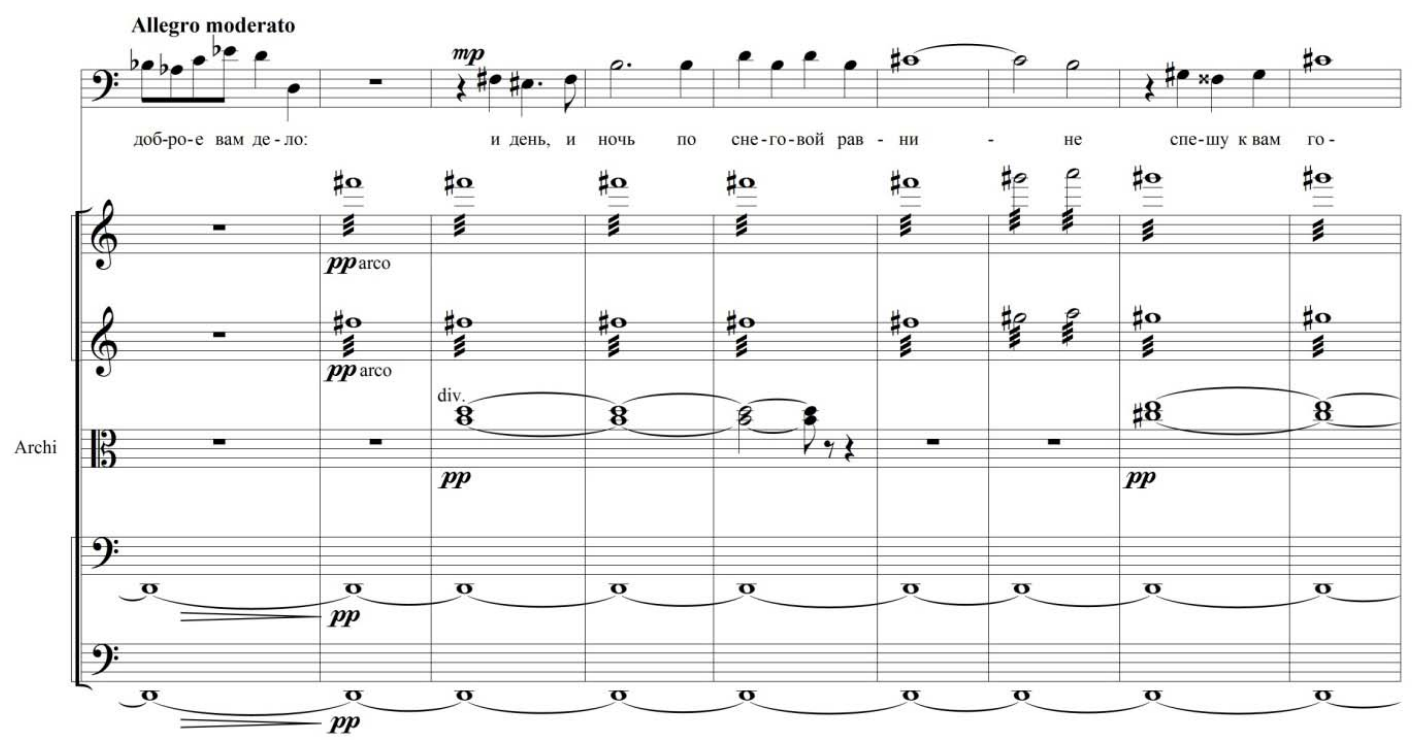

The elegiac, sad and sublime character of vocals, sounding on the background of tenderly gentle tremolo of strings, the lyrical cantilena of melodic turns (rounded ends of phrases, second singings, smoothing the activity of ascending fourth intonations, 'swaying' romance thirds) transmit the romantic nobility of nature, revealing a completely another facet of the image of Chatsky, who appears to be sensitive, sincere, loving.

Note that in the melodic line of the theme of arioso the close relationship with the $2^{\text {nd }}$ sharply expressive leitmotif of Chatsky is revealed; it represents its sung intonation and rhythm variant. However, being included in the voice part, changing the semantic context, the theme shows very different properties, namely, the emotional excitement, sincerity and warm-heartedness. Initially, it appears in the episodes associated with the manifestation of lyrical feelings for Sophia (they are mainly concentrated in the $1^{\text {st }}$ scene, where the character is elated with hopes for a mutual feeling). At the same time, the continued existence of the theme suggests the expansion of its semantic boundaries; the musical analysis reveals that it has a nature of theme-thesis and is the main intonation 'fund' of the voice part of Chatsky. In all subsequent dialogical scenes in which Chatsky participates (including his monologues), we can discover its different pitch and intonation variants (primarily referring to the voice part).

We shall turn our attention to how the composer presents the famous aphorisms by Griboyedov put into the mouth of Chatsky. Among the variety of the 'winged' phrases of the comedy the composer left only four ones, such as 'Blessed are the credulous for they are carefree' (fig. 37); 'I rarely nourish hopes. I hardly ever do' (7 t. before fig. 45); 'I'd love to serve. Servility is what I hate' (fig. 58); 'Sometimes I visit women but not with that intention' (fig. 104). They are all united by a common theme, intonationally related to the theme of the voice part from the $1^{\text {st }}$ monologue of Chatsky. G. Banshchikov surrounds the word of the writer with 'a special respect' (E. Finkelstein), as if inserting them 'in the frame'. This is expressed in the emphatic diatonicity of voice and orchestral parts (as opposed to the prevailing condensed-chromatic harmonic 
vertical of the opera), a clear tonal logic (C-dur in three cases), a deliberate isolation in the score by textured attenuation. The choral texture of accompaniment in brass and string instruments provides a noble-staid, preceptive character of aphorisms.

In general, Chatsky has the largest number of deployed monologues in the opera in comparison with other actors (in spite of the fact that the composer originally subjected the text of his remarks to maximum reduction). Of course, this is due to the literary source, for monologues by A. Griboyedov disclose the life credo of his character. Representing the thoughts and beliefs of Chatsky, they reflect different stages of the dramatic action, focusing a substantial sense of his drama inside themselves. We will highlight important monologues in the drama of the opera.

The central monologue from the $1^{\text {st }}$ action (Scene 2) 'I wonder who the judges are!'(fig. 77 , h-moll) is a continuation of the dialogue- encounter of Chatsky with Famusov ('I'd love to serve. Servility is what I hate'; 'That's it! You're all puffed up with pride and aspiration!'), revealing the polarity of their worldviews.

The character is flooded with a sense of patriotism and rejection of the opportunistic philosophy of everyman. The angry, revealing nature of his sayings is emphasized with the syllabic pronunciation of the text, $\boldsymbol{f}$ and $\boldsymbol{f} \boldsymbol{f}$ dynamics, the predominance of chased rhythmic figures, a wide range of the melodic line, sweeping rhetorical intonations of the declamatory voice part (often switching to the chant), in which the intervals of quart, newt and sevenths are accented. At the same time, the expressive musical speech of Chatsky implicitly maintains lyrical signs that appear in the singsong extended melodic phrases, descending second endings, sixth phrases with subsequent filling. All this points to the sincerity of the spoken word, the true nobility of the individual, upholding high ideals.

\section{Pattern 6}

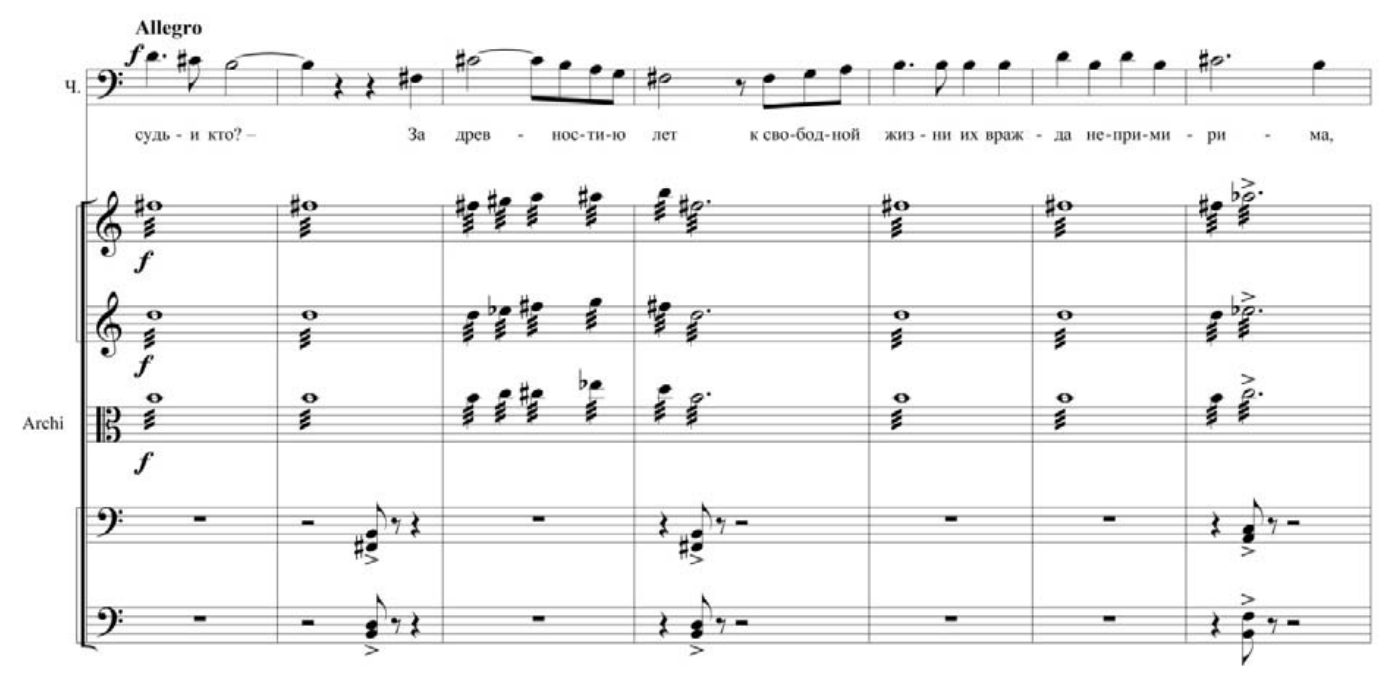

Another image of Chatsky, which is important in drama, is revealed in the monologue 'There in that room the little Frenchman from Bordeaux ...' (fig. 151, c-moll). It sounds in Act 2 , creating a sharp emotional and psychological preceding contrast to the previous scene of 'slander'. In semantic terms the monologue is perceived as a continuation of patriotic 'political' speeches of the character from Act 1 as the culmination of his civic position in relation to the 
sanctimonious 'high society'. The excited active character of the voice part of the song-arioso constitution (the $1^{\text {st }}$ section) is created by the moving rate, the wide singing range, the iambic structure of melodic phrases and the motion on the tones of c-moll triads. The central accusatory section of the monologue is a grotesque 'story from another person', which is turned by a vocalvoice modulation into recitative declamatory type of intoning. The ironic, sarcastic, parodic tone of the musical speech of Chatsky, ridiculing detractors ('Oh France! The land beyond compare!'; 'Can European culture be compared with our culture?'), is presented with a fussy patter (with a predominance of short, narrow in volume, chromatically twisting melodic phrases, sixteenth times) recitation with syllabic chants, which are all methods that are absolutely unusual for the musical speech of Chatsky in general. However, they are the best way to describe the false hypocritical essence of the society that surrounds the character.

The last monologue- aria of Chatsky 'I try to come to reason, but I can't...' (the finale of Act 2, fig. 189) represents the culmination of the lyrical line and the climax of both plot and dramatic lines. It is no coincidence that G. Banshchikov wrote the longest solo episode in opera (126 times), structurally emphasizing the final stage of the dramatic action. The voice part of the first section of the monologue consists of short, quietly sounding melodic phrases in the background of stiff orchestral ostinato, 'broken' with long pauses, transmitting shock, numbness and confusion of the character crushed with a 'double' betrayal of Sophia, and therefore lost for words. In the following, the tragically detached emotional state of Chatsky is replaced by the accusatory tone,
'I'm blind! I wanted a reward...!' (fig. 190). This is reflected in the change of dynamics $(\boldsymbol{f})$, high tessitura, chromatically fractured melodic phrases of the vocal speech, in which broad, affirmativedetermined intonations appear (quarts and newts are accented). The famous words "The coach, the coach!" are highlighted with $\boldsymbol{f f f}$ dynamics and sweeping triton-octave jumps. The emotional and psychological stress of the monologue utterly increases the resounding 'rumbling' of a bass drum (ostinato in the rhythmic progression), and the final monologue symbolizing the emotional shock of deceived and slandered Chatsky...

Continuing the analysis of the thematic sphere of the character, we identify the significant motif in the figurative and intonation drama of the opera. We will denote it as a leitmotif of 'madness'. It belongs to the group of 'situational' leitmotifs, as it appears in the ball scene (Act 2) at the time of the decision of Sofia to revenge Chatsky for the insult (t. 8 after fig. 133), 'You are fond of making fun, there's a cap and bells for you, young man! Take it or leave it'. The leitmotif is a rising minor second, sounding in the high register (xylophone, piano). Its role is revealed in a subsequent scene of 'slander' (226 times), namely, in the semantic center of Scene 3. It is the only choral scene, whose dramaturgical load is great; it is the culmination of the social line. The scene of 'slander' is built on a throughcomposed principle, following the text of where the gossip about Chatsky is growing and 'inflated'. The composer brilliantly embodies this with musical means: the 'hard' energy of the ostinato tone representing the rhythmovariant of the leitmotif of 'madness' acts as a launched pulse generating dramatic tense (see from fig. 135 to fig. 149). 
Pattern 7

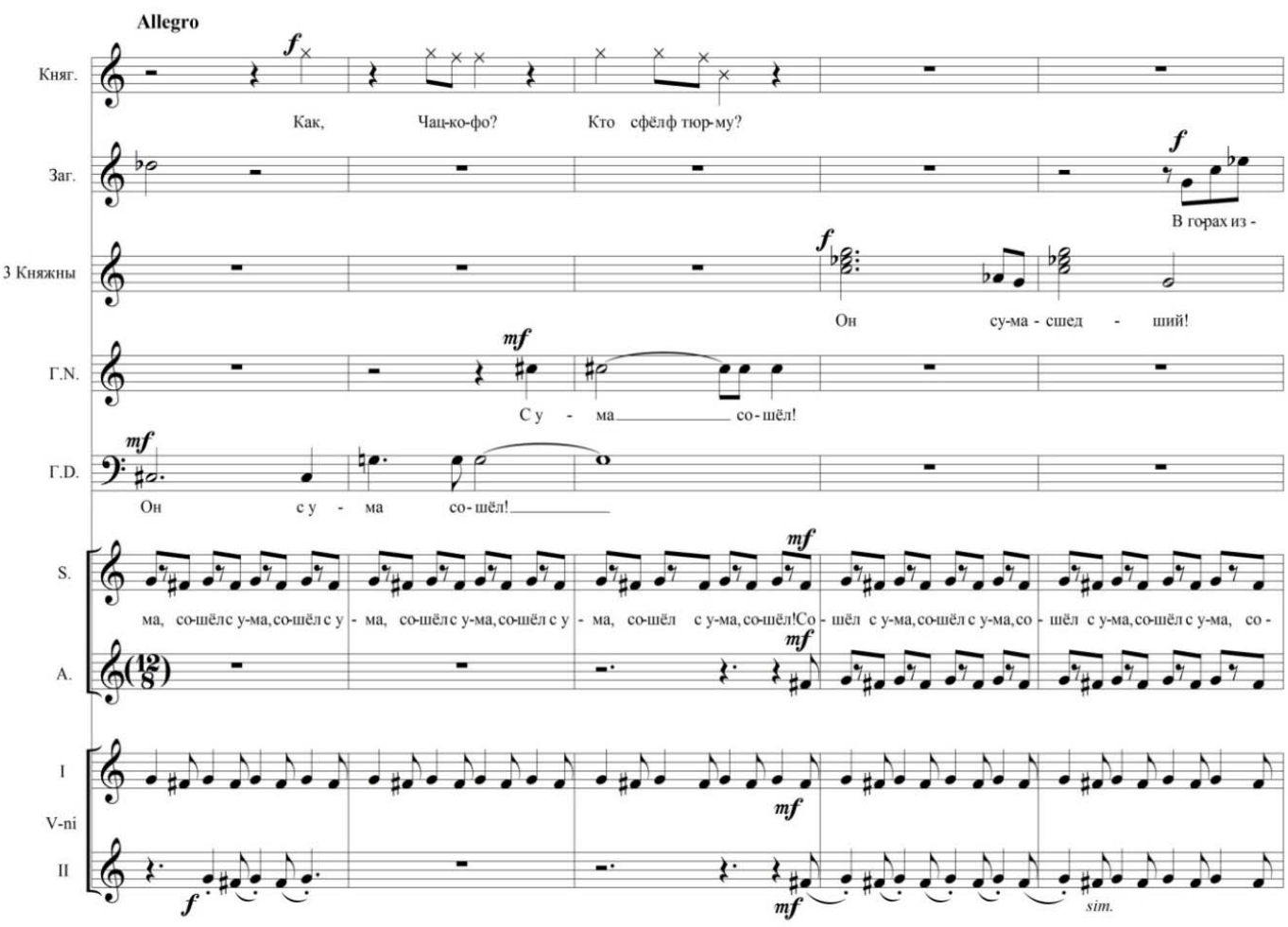

The voice parts in the counterpoint with replicas gradually merge into a mandatory sentence for the character: the chorus chants in unison, 'He's mad!'. The hysterical state of the crowd is represented by means of a multiple repetition of the same phrases, creating a striking effect of 'beating with the text', the opening of which was carried out by D. Shostakovich in the opera "The Nose". The leitmotif of 'madness' tragically sounds in the symphonic conclusion of the opera in a very high register of $\boldsymbol{f} \boldsymbol{f} \boldsymbol{f}$ celesta and piano: that is how the author sums up the events, indicating the collapse of Chatsky's illusions, his inability to confront the society of Famusov.

The image of the main character is related to another theme, which first appears in Scene 2 (Act 1). It sounds in a muffled manner in an octave presentation by the lower strings and celesta, which gives it a gloomy, partly infernal flavor. The emotional appearance of the first phrase of the theme is defined by lamento seconds with a long stop at the fis tone linked in the motion of various direction, representing distress, 'the painful thought' of the character; the second phrase is distinguished by the interval of the ascending minor third with the meaning of a question - Chatsky experiences serious reflections on Sophia. We will note the 'kinship' of the theme with the $2^{\text {nd }}$ leitmotif of the character (rhythmointonation variant in the mirror addressing), as well as with the voice theme. All this shapes their inextricable semantic link.

Given the situational context of the emergence and further functioning of the theme, we denote it as a leitmotif of the 'apprehension' of Chatsky. It is not by chance that it appears only in Scene 2. In Scene 1, burst like a whirlwind, the character is elated with blond dreams, hopes, full of joy, anticipating a meeting with his beloved. In Scene 2, he appears depressed because of the 
'cold' meeting with Sophia, doubt and anxiety creep in his soul. The inclusion of the leitmotif in the orchestral texture is due to the stage situation and are always associated with Sophia, representing the state of Chatsky, tormented with guesses about who his opponent is.

The relationship with the previous leitmotif is shown by another through-composed theme of the opera, which appears in a symphony intermission between Scene 1 and Scene 2 (fig. 49). Three textural layers can be identified in it. The first is a unison-call of woodwinds and pipes with a mute, which alarmingly 'pulses' with the eighth durations. The second is ostinato, sustained with the whole durations, 'sinister' chords of low copper $\boldsymbol{f}$ with accentuation of harmony of the diminished seventh chord. The third layer is formed by the ostinato campane part.

The pairing of these means of expression, of course, gives tragic semantics to the theme. Its functioning in the musical drama suggests the relationship with the image of the character. At the same time, the context of inclusion in the score allows defining it as a theme of Destiny of Chatsky that is supported by the orchestra development, stable in intonation, rhythm, timbre and tonality-harmonic terms (only the pitch position changes). All this reinforces the inexorable, imperative nature of the theme, which embodies the impersonal principle, which dominates Chatsky.

The theme sounds four times in the opera, determining the stage situations related to the stages of development of both dramatic lines. For example, it introduces the 'turning' dialogue of the characters in Act 2 (the scene at the ball, fig. 128), in which Chatsky tries to explain himself, make Sophia be frank. Its inclusion in the orchestral texture determines the outcome of the conversation, dramatizing the psychological atmosphere of the scene. In the Scene 4 the theme appears twice, anticipating the final denouement: in the first case Chatsky hears bad words about himself from leaving guests and decides to hide in the hallway ('I'll stay and keep an eye on it till morning. Once I am to drain a cup of woe, let it be so', fig. 171). Another (the latest) statement prepares the character's monologue 'I try to come to reason, but I can't...' (6 t. to fig. 189), revealing the psychological state of Chatsky whose consciousness is filled with pain from the mental wound inflicted by a double betrayal of the woman he truly loves.

The scope of Doom, Destiny is also related to the through-composed tritone motif $f-h$, which is performed by a group of percussion instruments (timpane, tam-tam). It forms a single negative semantic complex together with the theme of Destiny, madness, 'apprehension'. Let us call the three key drama areas of the functioning of the tritone motif in the score. Thus, first appearing in the orchestral ending of Scene 1 (fig. 48, t.7), $f$ - $h$ tritone (the whole ostinato episode is formed) is perceived as a sinister omen of the dramatic climax of events (the use of the rhythmic figure of the Beethoven theme of Destiny in this episode has a signsymbolic meaning). In the scene of the 'slander (Act $2 /$ Scene 3) the tritone motif, which constitutes the basis of the ostinato orchestral accompaniment, reveals a hostile, aggressive nature of the representatives of the Moscow society, holding up Chatsky to madness. Its semantics is revealed in the orchestra conclusion of the opera (fig. 199). The ostinato tritone motif sounding in the part of percussion instruments in the original rhythmovariant, summarizes the events, sphering the image scope of the character in a single semantic space.

Thus, the example of the dramatic image of Chatsky allows us to see how G. Banshchikov managed to reveal, using the expression by Iu.Tynianov, 'the tragedy in the form of comedy'. The composer himself calls his work 
a drama that points to a deep understanding and interpretation of the writer's work. The genre definition of opera may be specified and described as a drama-satire, because, on the one hand, it presents the love story of the character, and on the other hand, the social conflict of Griboyedov's work, which was originally crucial to the comedy, is equally significant for G. Banshchikov.

Such a method of work, which is the maximum immersion in the imagery world of a literary source with the identification of its artistic dominants, is shown by the composer in all subsequent works for the musical theater.

\section{References}

Voitkevich, S. (2014). Proizvedeniia F.M. Dostoevskogo na dramaticheskoi i muzykal'noi stsene [The creative works by F.M. Dostoyevsky on a drama and musical scene], In Zhurnal Sibirskogo Federal'nogo Universiteta. Gumanitarnye nauki [Journal of Siberian Federal University. Humanities \& Social Sciences], 7 (1), 43-49.

Deval'er, M. (2011). Dialog kul'tur v prostranstve khudozhestvennogo proizvedeniia [The dialogue of cultures in the space of fiction], In Voprosy kul'turologii [The Culturology Issues], 9, 75-81.

Kholodova, M. (2014). Komicheskie opery G.I. Banshikova v kontekste razvitiia otechestvennogo muzykal'nogo teatra 2-oi poloviny XX veka [The comic operas of G.I. Banshchikov in the context of development of the domestic musical theatre of the second half of the $20^{\text {th }}$ century], In Zhurnal Sibirskogo Federal'nogo Universiteta. Gumanitarnye nauki [Journal of Siberian Federal University. Humanities \& Social Sciences], 7 (1), 50-58.

Kholodova, M. (2011). «Zazerkal'e» muzykal'nogo teatra G.I. Banshikova: «In arsveritas» ['The mirror-world' of the musical theater of G.I. Banshchikov: 'In arsveritas'], In Muzykal'naia zhizn' [Musical life], (2), 8-9.

\section{Образ Чацкого в опере «Горе от ума»}

\section{Г.И. Банщикова}

М.В. Холодова

Красноярский государственныий институт искусств Россия, 660049, Красноярск, Ленина, 22

Геннадий Иванович Банщиков - один из выдающихся композиторов современности. В статье изложены некоторые результаты исследования музыкально-театрального наследия Г.И. Банщикова.

В иентре внимания автора - опера композитора, созданная на сюжет знаменитой комедии А.С. Грибоедова. Сквозь призму анализа образа главного героя произведения - Чаикого - демонстрируется мастерство автора-драматурга, раскрывающего музыкальными средствами художественно-смысловые контексты литературного первоисточника.

Ключевые слова: Г.И. Банщиков, отечественный музыкальный театр, русская классическая литература, опера.

Научная спещиальность: 24.00.00 - культурология. 